\title{
菩提流志訳『須摩提経』の流伝と入蔵
}

一七寺一切経本を中心として——

\section{張美 僑}

\section{1. はじめに}

菩提流志 ( ? 727) 訳『須摩提経』は竺法護訳『須摩提経』, 鳩摩羅什訳『須 摩提菩薩経』の同本異訳である．また，本経は『大宝積経』「妙慧童女会」の別 生経であることから, 『開元釈教録』の規定によって入蔵経典から排除されるこ とになった。

通常, 権威を持つ経録によって「不入蔵」の烙印が押された経典は大蔵経の中 へ復帰することは難しいが, 菩提流志訳『須摩提経』はその例外であった．漢文 大蔵経のうち北方系統の契丹蔵・房山石経, 及び江南系大蔵経は竺法護と沜摩羅 什の二訳を収録しているのに対して，開宝蔵をはじめとする中原系大蔵経では羅 什訳が排除され，菩提流志訳が採録されているのである ${ }^{1)}$.

さらに，菩提流志訳は日本の平安時代に書写された七寺一切経中にも確認され る. 本稿では, 七寺一切経中の菩提流志訳『須摩提経』の祖本の特定を試みる.

\section{2. 七寺一切経本菩提流志訳『須摩提経』の祖本の検討}

\section{1. 七寺一切経本の祖本と想定される諸本}

『尾張史料七寺一切経目録』中には,「須摩提経」と「須摩提菩薩経」の二経が 見出される ${ }^{2}$. 目録上ではいずれも訳者名は示されていないが，日本古写経デー タベースにより両者の内容を確認すると,「湏摩提菩薩経」とされる方は笙法護 訳であり，もう一方の「湏摩提経」は, 「大唐三蔵法師菩提流志奉 詔譯」と訳 者名が書かれており，また内容からも菩提流志訳であることが確認できる ${ }^{3)}$.

七寺一切経本の祖本の特定にあたり，まずは開宝蔵本以外の系統のものが日本 に存在した可能性について述べる。 天平七年（735）, 入唐僧玄昉（?～746年）は 『開元釈教録』及びそれに基づき書写された仏典群を請来し，その翌年には光明 皇后の主導のもと，それらの仏典を底本とした一切経（五月一日経）の書写が始 まった。 その際の仏典借用記録である「写経請本帳」には ${ }^{4)}$,「須摩提経一巻」 
という記載が確認できる。この記録には訳者名が記されていないため,「須摩提 経一巻」が菩提流志訳である可能性がある.

さらに, 石山寺一切経中には, 底本不明の菩提流志訳『須摩提経』が現存して いる，筆者はまだその写本を実見していないが, 『石山寺の研究 一切経篇』に よれば5), その奥書は以下の通りである(下線は筆者).

一交了

以賀茂本比交了

殊勝經二成了

賀茂經藏本云 件本以法成寺唐本比校云 引

定暹勘申云此經大寶積經妙惠

童女會也專非目錄所載羅什之

翻本也須摩提之題大謬也法城

寺海彼之摺摺本謬同前希有

引 引 可求監什本而已

※「摺」字に塗抹・改聜あり

この奥書によれば，石山寺一切経本は「法成寺唐本」(「法城寺海彼」の摺本）と 対校した「賀茂経蔵本」を用いて対校したものであるという。法成寺には，10世 紀に䢛然（938～1016）が請来した開宝蔵が納められていたことが知られ，「法成 寺唐本」はその開宝蔵を指すと思われる。

「法成寺唐本」が開宝蔵本であるならば，これを校本に用いた「賀茂経蔵本」 は開宝蔵以外の系統のものと推測される。 また,「法成寺唐本」との比校を経て 経文が改められた「賀茂経蔵本」を校本に用いた石山寺本の底本も, 開宝蔵以外 の系統であった可能性がある.

日本に開宝蔵以外の系統の『須摩提経』が存在したこと，また石山寺一切経の 多くが天平写経を底本に用いたことを勘案すれば，玄昉請来の「須摩提経一巻」 が菩提流志訳であり，五月一日経や「賀茂経蔵本」としてその内容が受け継がれ ていた可能性がある。こうした推測のもと, 本稿では玄昉請来の菩提流志訳『須 摩提経』の存在を想定し, 開宝蔵本系統に対して古写経本系統と仮称する. 未た その祖本が明らになっていない七寺一切経本も, この古写経本系に属する可能性 がある。

\section{2. 七寺一切経本と開宝蔵系の菩提流志訳『須摩提経』との校異}

七寺一切経本の祖本が開宝蔵本であるか古写経本であるかを検討するため, 七 寺一切経本と開宝蔵本との本文校異を行う。なお, 開宝蔵本はすでに散逸してい 
るため, 代替として，開宝蔵の覆刻版である金蔵と高麗再雕蔵を用いた.

本文校異の結果として，七寺一切経本と金蔵・高麗再雕蔵とが一致しなけれ ば, 七寺一切経本は開宝蔵本系ではなく, 古写経本系に属すると考えられる。し かし, 現時点では古写経本系の経文は得られていないため, 七寺一切経本と金 蔵・高麗再雕蔵とが一致した場合, 七寺一切経本が古写経本系であるか開宝蔵系 であるかは，判断できないことになる.

両者の本文校異の結果のうち，異なる箇所は以下の通りである.

表 七寺一切経本と金蔵・高麗再雕蔵との相違

\begin{tabular}{|c|c|c|c|c|c|c|c|}
\hline & 七寺本 & 金蔵 & 高麗再雕蔵 & & 七寺本 & 金蔵 & 高麗再雕蔵 \\
\hline 1 & 護念久住 & 護令久住 & 護令久住 & 6 & 非耶非捨 & 非取非捨 & 非取非捨 \\
\hline 2 & 不諦菩薩 & 不謗菩薩 & 不謗菩薩 & 7 & 如若幻化 & 如若干幻化 & 如若干幻化 \\
\hline 3 & 不求過去 & 不求過失 & 不求過失 & 8 & 心心而量 & 心心所量 & 心心所量 \\
\hline 4 & 是提行 & 是菩提行 & 是菩提行 & 9 & 為其作曰 & 為其作礼曰 & 為其作礼曰 \\
\hline 5 & 何以此等 & 何以故此等 & 何以故此等 & 10 & 白汝等 & 旦汝等 & 旦汝等 \\
\hline 11 & 法明不滅 & 法眼不滅 & 法眼不滅 & & & & \\
\hline
\end{tabular}

異なる 11 箇所のうち 1 ～ $3,6,10,11$ の例は極めて近似した字形による相違で あり，4，5，7，9の例は七寺一切経本の誤脱である.この結果より，11箇所の相 違はほぼ寺一切経本の誤写であると考えられ，七寺一切経本と開宝蔵系との間 には近似性があると言える。すなわち，七寺一切経本が開宝蔵本系の転写である か, あるいは古写経本系の転写であるか, どちらとも判断できないという結果に なった。

その他の検討方法としては, 書写形態の比較による検討が可能と思われる. 刊 本から転写された写本には, 刊本が有する刊記や千字文等がそのまま転写される ことがある，実際に七寺一切経中にも，開宝蔵本の刊記が転写されている事例は あるが6)，日本古写経データベースにより本経の画像を閲覧したところ，刊記・ 千字文いずれも確認できなかった。 なお，開宝蔵系の刊本には，一行あたりの字 数が14文字であるという特徵がある。しかし七寺一切経本は, 開宝蔵の刊記が 見られるものでも，すべて一行 17 文字前後に改められてしまっているため7)，七 寺一切経本に関しては一行あたりの字数による判断は不能であった.

したがって, 書写形態の比較によっても, 七寺一切経本が開宝蔵本系の転写で あるか, あるいは古写経本系の転写であるかは, 特定できなかった. 


\section{3. 結論}

以上，菩提流志訳『須摩提経』の流伝と入蔵について，日本に現存する七寺一 切経本を対象とし，その祖本を特定するために，開宝蔵本系とは別に古写経本系 がある (玄昉請来経) と仮定して，七寺一切経本と開宝蔵系の金蔵・高麗再雕蔵と の本文校異を行った。校異の結果，七寺一切経本と開宝蔵本系の経文の間には近 似性が見られたため, 古写経本系に属するか否か判断できず，一方で，開宝蔵本 との間に書写形態上の類似点も見られなかったため，開宝蔵本系に属するという 確証も得られなかった。

根本の問題は, 古写経本系の祖本である唐代写本と, 開宝蔵本の底本となった 唐代写本とが同系統であるか異系統であるかが明らかでないことである。この問 題はやはり，古写経本系の経文が明らかにならない限り解決不可能である.

古写経本系である可能性を有し，かつ現存が確認されている石山寺一切経本の 調査が，今後の課題となる.

1）このことは高麗再雕蔵に収録されている守其『高麗国新雕大蔵校正別録』（1246年）に見 られる次の記述により知ることができる．「開元録云，此經前後四譯，三存一關．流志法師 有先後二譯, 其先譯者, 即一關也. 今撿諸藏, 國, 宋二蔵有法護譯, 流志後譯, 而無什譯. 丹藏雖無流志後譯, 而有法護, 羅什二譯」(東國大学校發行『高麗大蔵経』第38冊, 1976, 513頁)。 2）七寺一切経保存会『尾張史料七寺一切経目録』(1968，27頁)。 3）日本 古写経データベース https://koshakyo-database.icabs.ac.jp/. 4）東京大学史料編纂所編纂 『大日本古文書』編年之7 (東京大学出版会, 1983, 68頁).

5）石山寺文化財綜合調査団 編『石山寺の研究一切経篇』(法蔵館, 1978, 105-106頁)。 6) 『尾張史料七寺一切経目録』 (113，121頁）によれば, 『出三蔵記集』巻十一, 『集諸経礼㙨儀』巻上の末尾には開宝蔵の 刊記が転写されているという。 7）日本古写経データベースにより, 七寺一切経本のう ち開宝蔵の刊記・千字文を有する写本（注6を参照）の画像を確認したところ，いずれも一 行 17 文字前後であった.

〈参考文献〉

守其『高麗国新雕大蔵校正別録』東國大学校發行『高麗大蔵経』に収録, 1976.

『尾張史料七寺一切経目録』七寺一切経保存会, 1968 .

東京大学史料編纂所編『大日本古文書』東京大学出版会, 1983.

石山寺文化財綜合調査団編『石山寺の研究一切経篇』法蔵館, 1978.

〈キーワード〉 菩提流志訳, 『須摩提経』, 不入蔵, 七寺一切経, 日本古写経 (国際仏教学大学院大学) 